\title{
Agile Product Development Practices for Coping with a Learning Paradox in R\&D Offshore Units
}

\author{
Janne Kuivalainen, Iivari Kunttu, Marko Kohtamäki
}

\begin{abstract}
" [The product development] person has to feel that a customer is looking over their shoulder, one who is really looking for some added value that we can deliver by leveraging our systems. That's one of the key principles of how we develop ourselves, how it drives our innovation."
\end{abstract}

Interviewed Head of R\&D offshore unit

\begin{abstract}
$R \& D$ offshoring involves the relocation of in-house $R \& D$ activities to subsidiary units located in other countries, often associated with low-cost engineering work, to meet global operational requirements. The main motivation behind R\&D offshoring by global technology companies is usually to utilize local resources, knowledge, and competencies provided by geographically dispersed subsidiaries in the most effective manner, which in most cases involves high expectations for project performance. However, offshore units often have their own local interests, such as developing their activities to compete with the company's other global $\mathrm{R} \& \mathrm{D}$ units, by not only building their project performance, but also demonstrating learning and innovativeness. This causes a learning paradox in which the R\&D unit is expected to possess capabilities for innovation and learning, while at the same time demonstrating a high product development performance. This paper presents a qualitative case study that analyzes how $R \& D$ managers in the offshore units of a global technology company can cope with conflicting tensions between learning and performance. The results present a variety of coping practices that are based on developing local innovation strategies, constant learning, and supporting local innovation culture. The results also underline the meaning of agile working models in facilitating local innovation activities.
\end{abstract}

\section{Introduction}

As an important part of globalization, the world has witnessed a movement of industrial manufacturing work from developed countries to countries associated with low-cost operations. However, over the last few decades, knowledge-intensive product development work has increasingly shifted from high-cost developed countries to countries with lower costs of engineering work, and the internationalization of research and development $(R \& D)$ activities has emerged as an important practice for global technology companies. The internationalization of high value-added product development activities has been referred to as "the next generation of offshoring" (Einola et al., 2017). R\&D offshoring provides companies with opportunities to gain competitive advantage by utilizing skilled and costeffective labor in emerging markets (Parida et al., 2013). In this manner, $R \& D$ offshoring can be seen as a process whereby a globally operating company relocates its inhouse product development activities to other countries, often associated with low-cost engineering work. Integrating the capabilities owned by these offshore units is a special advantage of global technology companies (Yamin \& Andersson, 2011), and utilizing the competencies and capabilities developed in these units may help the parent unit to improve the company's competitiveness (Birkinshaw \& Hood, 1998). Previous studies have shown, however, that the coordination of $\mathrm{R} \& \mathrm{D}$ activities across geographically dispersed units is a challenge for the parent units, which in turn may have a negative impact on R\&D performance (Parida et al., 2013).

On the other hand, because subsidiaries are typically embedded in various local networks in their own geographic regions, they may develop and maintain unique and idiosyncratic patterns of network linkages. This, in turn, helps the subsidiaries to be exposed to new knowledge, ideas, and opportunities provided by their local networks (McEvily \& Zaheer, 1999). This differential exposure has been regarded as one of the basic 


\section{Agile Product Development Practices for Coping with a Learning Paradox in R\&D Offshore Units Janne Kuivalainen, Iivari Kunttu, Marko Kohtamäki}

competitive advantages of multinational firms, because it increases the breadth and variety of network resources (Ambos et al., 2010; Andersson et al., 2002). As the main motivation of the parent unit (or headquarters) is to utilize the local resources, knowledge, and competencies provided by the geographically dispersed subsidiaries in the most effective manner, the offshore subsidiaries often have their own local interests to develop their activities. This is because the subsidiaries frequently have to compete with each other in the company's global $\mathrm{R} \& \mathrm{D}$ unit network in order to maintain or increase their status in the view of headquarters. In this context, the R\&D offshore units located in countries with a relatively low cost of engineering work have to maintain and develop their project performance, as well as demonstrate learning and innovativeness to the parent unit(s) (Kunttu et al., 2019). In this manner, offshore units attempt to maintain and improve their position among other $R \& D$ units with whom they are competing globally, not only by offering a lower cost of work, but also by their resources and capabilities ( Lewin at al., 2009; Bäck \& Kohtamäki, 2016; Kunttu \& Kohtamäki, 2018). This means that offshore units have to demonstrate innovation performance by engaging in strategic goals and targets set by the current competitive environment, and the views of headquarters (Ambos et al., 2010). This, in turn, means that the managers of the R\&D offshore units are increasingly facing a dilemma of how to encourage their product development staff to engage in exploratory innovation, and to simultaneously ensure that the R\&D function meets its performance targets in terms of project timings and costs (Lewis et al., 2002). This general dilemma is shared by $R \& D$ managers in countries with both a high and low cost of engineering work, and it can be seen as a learning paradox, in which the $R \& D$ organization is expected to have high innovation performance and learning capabilities, yet at the same time must simultaneously demonstrate high project performance (Kunttu \& Kohtamäki, 2018; Kunttu et al., 2019). The previous literature on organizational paradoxes shows that these kinds of situations can seldom be solved, but rather that organizational members may develop practices to navigate them by "both-and" thinking ( Smith \& Lewis, 2011; Jay, 2013; Kohtamäki et al., 2020).

In this paper we focus on improving the understanding of how R\&D offshore units located in countries with a low cost of engineering work may develop their dynamic capabilities to compete with other $R \& D$ units in the same company, not only in terms of labor costs, but also based on their product development skills and capabilities. This is an obvious learning challenge for newly-established offshoring units, provided that they may occur at significant geographical distances from their parent or partner units, and often have a limited knowledge base, with different cultural backgrounds (Einola et al., 2017). For this reason, local R\&D management has to make efforts to develop and learn the new capabilities of these units.

Thus, this study aims to answer the following research question: How can managers of $R \& D$ offshore subsidiaries develop learning capabilities and at the same time maintain project performance? This study addresses the research question by analyzing the coping mechanisms related to the learning-performance paradox, and by both identifying the managerial practices that facilitate simultaneous engagement in project performance targets and, at the same time, maintaining learning and innovation performance. The qualitative case study is based on interviews conducted in offshore units of a global technology company located in Poland. In this manner, this study contributes to the research work on R\&D offshoring by presenting practices of learning and competency development in $R \& D$ offshore units. The findings of this paper can have important managerial implications, given that global technology companies are increasingly offshoring their knowledge-intensive $R \& D$ work to countries with lower costs of engineering work.

\section{Developing dynamic capabilities in R\&D offshore units}

R\&D units of technology firms often operate in dynamic environments characterized by strong competition, rapid changes, accelerating product life cycles, changing customer expectations, and product discontinuities (Marsh \& Stock, 2003). In addition to these general challenges, geographically dispersed R\&D subsidiaries have to cope with tensions caused by project performance expectations set by their parent units, and on the other hand, demonstrate learning and innovation capabilities (Kunttu \& Kohtamäki, 2018; Kunttu et al., 2019). To successfully develop and sustain their competitiveness under these environmental circumstances, the technology units need to develop dynamic capabilities that enable them to draw on, extend, and redirect their technological capabilities and R\&D resources (Marsh \& Stock, 2003). Dynamic capabilities have been defined as: “The firms' processes that use resources - specifically resources to integrate, reconfigure, gain, and release resources - to match and even create market change. Dynamic capabilities thus 


\section{Agile Product Development Practices for Coping with a Learning Paradox in R\&D Offshore Units Janne Kuivalainen, Iivari Kunttu, Marko Kohtamäki}

are the organizational and strategic routines by which firms achieve new resource configurations as markets emerge, collide, split, evolve, and die." ( Teece et al., 1997). Accordingly, dynamic capabilities represent organizational processes by which an organization's actors employ their resources to develop new value creation. Creating and maintaining valuable resources, skills, and capabilities can be an important dynamic capability for geographically dispersed $R \& D$ units when they contribute to a company's common R\&D targets.

Previous research in the area of business relations has acknowledged that subsidiaries often contribute a parent company's competitiveness through innovation, knowledge sharing, and transfer, as well as by identifying new business opportunities (Reilly et al., 2012; Reilly \& Sharkey Scott, 2014). Literature on the role of $R \& D$ subsidiaries emphasizes the processes of initiative-taking and utilizing local opportunities in the competition between subsidiaries (Ambos et al., 2010; Figueiredo, 2011). Both of these activities can serve as a means for coping with the competing demands of learning and performance in the subsidiaries. Enterprising subsidiaries may utilize their specific and sometimes unique local knowledge, as well as their specific skills and competencies to generate initiatives (Figueiredo, 2011). This kind of initiative generation may mean that the subsidiary unit develops internal innovation by taking advantage of its own capabilities or local opportunities (Kunttu et al., 2019). However, as offshore units typically have only minimal power to make decisions concerning their own projects and tasks, they have to find ways to allocate their resources for their own innovation development work. For this reason, internal development work typically takes place in isolation, and often without explicit approval from the parent company (Reilly et al., 2012). In this paper, we concentrate on managerial practices that may facilitate this kind of internal innovation development in $R \& D$ offshore units.

\section{Methodology}

This paper is based on a qualitative case study approach and examines three $R \& D$ offshoring units in a global high-technology firm. The R\&D units in question are all located in Poland, and represent product development capabilities of large high-technology firms operating in various areas of information technology. Table 1 summarizes the information gathered on the three $R \& D$ units. The empirical data collected for the study involved interviews based on discussions with managers of the $R \& D$ and innovation functions in each unit. The selected interviewees were key decision makers concerning $R \& D$ and innovation in their organizations, as listed in Table 1. All the interviews were recorded and transcribed. The interview data were analyzed by the authors after the interviews were completed.

\section{Results}

In this section, we analyze the data acquired from three company case studies. The analysis is divided into three subsections. In the first subsection, we aim to find answers to the research question from the viewpoint of strategy-based management, by identifying local-level innovation practices that help managers to cope with tensions between learning and performance. In the

Table 1. Description of case studies

\begin{tabular}{|c|c|c|c|}
\hline & Case Study A & Case Study B & Case Study C \\
\hline Location & Poland & Poland & Poland \\
\hline $\begin{array}{l}\text { Number of } \\
\text { employees in } \\
\text { R\&D unit }\end{array}$ & 330 & 200 & 18 \\
\hline $\begin{array}{l}\text { Main products/ } \\
\text { services }\end{array}$ & $\begin{array}{c}\text { Software development } \\
\text { and electromechanical } \\
\text { engineering }\end{array}$ & Software development & Software development \\
\hline $\begin{array}{c}\text { Position of the } \\
\text { interviewee }\end{array}$ & Head of the R\&D unit & $R \& D$ site leader & $\mathrm{R} \& \mathrm{D}$ team leader \\
\hline
\end{tabular}




\section{Agile Product Development Practices for Coping with a Learning Paradox in R\&D Offshore Units Janne Kuivalainen, Iivari Kunttu, Marko Kohtamäki}

second subsection, we analyze learning practices in local $R \& D$ teams. The third subsection focuses on practices supporting innovative culture at local level. Table 2 summarizes the identified managerial practices.

\section{Local innovation strategies}

In one of their case studies, Kunttu et al. (2019) found that the tension between exploitative project performance and explorative innovation spurs competition between the globally dispersed $R \& D$ units.

"Competition [between offshore units] means looking at quality, response time, need time, and customer satisfaction that drives a little bit more innovation and operational excellence on our side." - Case Study $B$

In practice, $R \& D$ performance is measured by quality, response time, on-time deliveries, or customer satisfaction. In addition to achieving short-term performance targets, $R \& D$ units have to simultaneously stretch their capacity to innovate and learn. In many cases, innovation and learning capabilities have been regarded as a competitive advantage for geographically dispersed R\&D units (Bäck \& Kohtamäki, 2016; Kunttu \& Kohtamäki, 2018). Local R\&D management should therefore accept the expectation of constant explorative learning in product development, while simultaneously maintaining competitive levels in project performance. At the local organization level, this can be regarded as a learning paradox. As has been indicated by the literature, these kinds of contradictory tensions can seldom be solved, yet organizational members may develop practices to navigate the paradoxes by "bothand" thinking ( Smith \& Lewis, 2011; Jay, 2013; Kohtamäki et al., 2020). Exploratory learning in R\&D subsidiaries can be facilitated by developing local innovation strategies that are often informal and salient (Kunttu et al., 2019). When asking R\&D managers about the factors that drive local innovation, direct customer engagement was emphasized:

"When we sit with external clients around the table and we are discussing what kind of futures our systems need, how they may cover the requirements and expectations ... [the product development] person has to feel that a customer is looking over their shoulder, one who is really looking for some added value that we can deliver by leveraging our systems. That's one of the key principles of how we develop ourselves; how it drives our innovation." Case Study A
Local R\&D management sees direct customer contact as key for local innovation and value creation. This can be regarded as initiative-taking at a local level (Ambos et al., 2010; Figueiredo, 2011), in which the R\&D unit develops and maintains its own relationships with customers, which in turn helps the subsidiaries get exposed to new knowledge, ideas, and opportunities that are provided by their local networks (McEvily \& Zaheer, 1999). As discussed in Kunttu and Kohtamäki (2018), local-level initiative-taking plays a key role when local $R \& D$ managers have to cope with the contradictory demands of learning and performance. These initiatives include local-level practices regarding innovation development work, which is typically implemented in an unofficial and salient manner. Thus, as $R \& D$ resources are mainly allocated based on project performance targets, local $R \& D$ management has to arrange "flexible time" for innovation, and the development of new ideas. The interview data revealed local-level practices for this:

"One of the ideas that we are trying to implement right now is that we have some fixed time inside the product slot of part of our capacity fully allocated to innovation ... we are trying to put some systemic space, or build the space, for this innovation to work with our processes, that they somehow ensure that we have time for that." - Case Study B

Interestingly enough, local $R \& D$ managers explained that by creating efficient and automated routines related to, for example, testing and administration, the R\&D unit may save time that can then be used for learning and innovation work:

"Continuous testing and continuous delivery of SW in every sprint enforces the quality and allows us to work with new ideas and technological innovations when they can be integrated into standard product development cycles. High quality enables innovation activities."-Case Study B

In the same manner, the costs related to time spent on innovation and administration are added as overheads to the product development hourly rate:

"We included in our real life a couple of hours or an amount of time people can devote to developing their idea.... This development can be also idea or innovation generation events, yes, so it means that I already calculated this as a part of our hourly rate."Case Study A 


\section{Agile Product Development Practices for Coping with a Learning Paradox in R\&D Offshore Units Janne Kuivalainen, Iivari Kunttu, Marko Kohtamäki}

\section{Supporting learning}

In all three cases, the meaning of constant learning was underlined as a necessary condition for innovativeness in each organization. The development of core competencies was seen as a strategic asset in the competition with other R\&D units:

"I believe what we need to learn is how to collaborate with partners, external partners. It means two things actually. The first one is to really fully and deeply understand what has to be on our side, what has to be our core competency, what has to be our very well integrated and embedded capability on our side. The second thing is partnership means dealing with our partners and making sure that we can develop this partnership very well in certain areas."- Case Study A

Again, initiative-taking in collaboration with external partners and customers was emphasized as a strategic learning challenge. Along with stating the importance of recruiting new and promising talents for R\&D work, the interviewed managers suggested a number of practices related to constant learning in their daily $R \& D$ work.

"We encourage people to actually try new technology, try new stuff, to go to some interesting conferences from which they actually can gain knowledge."Case Study C

"Going to different conferences and training regarding the technology and keeping people up to date with what's happening in the world and what are the efficient ways of coding, what are the efficient ways of ensuring quality and constantly learning, that's definitely one of the key elements of $R \& D$." - Case Study B

In addition to formal learning events such as training, courses, and conferences, the interviewees emphasized the importance of locally-invented learning practices, such as hackathons or learning workshops, in which the R\&D staff came together to watch live streams of conferences or engage in pair programming:

"We organize the hackathon after working hours so we start after $5 \mathrm{pm}$. The goal is actually to use some technologies that we are not working on every hour on a daily basis."-Case Study C

"To have the opportunity to do live streaming or to watch live streams online of different events like the
Microsoft Build or Google IO. Sitting in the in the afternoon watching and commenting and exchanging online what they are seeing, etc., commenting on those things." - Case Study A

"In shared learning events] they do the pair programming during that, and the pair that is programming is on the projector, on the big screen, and other people in the room can see how they code, what tools they use, what shortcuts they're using, things like that." - Case Study B

According to the interview responses, managers appreciated informal learning events as opportunities for their staff to get involved with new technologies. This in turn has led to initiative-taking on an individual level:

"People somehow, even maybe they don't realize, but being active after hours in different conferences, different communities, different meetups, they're processing what they see, what they learn at these events and immediately believe they associate the technology, the discussions they have around software technologies.... Usually, after such meetings, they are back to the office, they are approaching us as leaders, and they are saying, 'I have seen something good which we could potentially implement in our centre." - Case Study A

In all three cases, the product development organizations had adopted and deployed agile and lean development methods driven by iterative improvements. All three R\&D managers underlined the effectiveness of the use of agile principles, especially in terms of project performance. To support agile working models, R\&D organizations have full-time agile coaches for their teams. The role of these coaches is related more to mental models, rather than tools or processes:

"[T] he quality of our R\&D or quality of our work is definitely a full commitment to lean development and agile development. With each iteration, you can see what brings value, [and] what does not bring value. That's why we have a couple of agile coaches among our teams. They go through all teams and they check this mental model." - Case Study A

Again, the meaning of quality was emphasized. The interview data also present an interesting link between agile working procedures and innovation work:

"What we try to implement in our team is to so-called 


\section{Agile Product Development Practices for Coping with a Learning Paradox in R\&D Offshore Units Janne Kuivalainen, Iivari Kunttu, Marko Kohtamäki}

Table 2. Summary of the identified practices

\begin{tabular}{|c|c|c|}
\hline Topic & Practice category & Identified practices \\
\hline \multirow[t]{3}{*}{$\begin{array}{l}\text { Local innovation } \\
\text { strategy }\end{array}$} & Fostering local innovation & $\begin{array}{l}\text { Arranging flexible time for innovation work. } \\
\text { Workshops with external customers to verify needs, } \\
\text { requirements and expectations. } \\
\text { Drive for productivity and the utilization of automated tools in, } \\
\text { for example, testing and administration, increases time for } \\
\text { learning and innovation. } \\
\text { Opportunities for formal and informal learning. }\end{array}$ \\
\hline & Initiative-taking & $\begin{array}{l}\text { Developing and maintaining relationships with local partners. } \\
\text { Direct relationships with external customers. } \\
\text { Local innovative projects and initiatives that have an impact on } \\
\text { customer value. }\end{array}$ \\
\hline & $\begin{array}{l}\text { New ways of organizing } \\
\text { R\&D work }\end{array}$ & $\begin{array}{l}\text { Arranging flexible time for innovation by automating processes } \\
\text { related to, for example, administration and testing routines. } \\
\text { Including innovation time with daily project work. } \\
\text { Agile and lean development methods driven by iterative } \\
\text { improvements. Facilitation by full time agile coaches and focusing } \\
\text { on mental models instead of tools or processes. }\end{array}$ \\
\hline \multirow[t]{2}{*}{$\begin{array}{l}\text { LEARNING: } \\
\text { Supporting learning }\end{array}$} & $\begin{array}{l}\text { Identifying new } \\
\text { technologies }\end{array}$ & $\begin{array}{l}\text { Participating in learning events, conferences, and other events. } \\
\text { Hiring new talents who know new tools and technologies and } \\
\text { who can drive their introduction into old products. }\end{array}$ \\
\hline & $\begin{array}{l}\text { Supporting competency } \\
\text { development }\end{array}$ & $\begin{array}{l}\text { Pair programming workshops. } \\
\text { Hackathons. } \\
\text { Live streams from tutorials and learning events. }\end{array}$ \\
\hline \multirow[t]{2}{*}{$\begin{array}{l}\text { CULTURE: } \\
\text { Innovative culture } \\
\text { and structures }\end{array}$} & Innovation mindset & $\begin{array}{l}\text { Organizing guided hackathons where idea generation is framed } \\
\text { by challenges with the current product or service by product } \\
\text { management. } \\
\text { Measuring how many innovation ideas from hackathons and } \\
\text { other idea-generation workshops are delivered with products. } \\
\text { Encouraging "fail quickly" mindset. }\end{array}$ \\
\hline & $\begin{array}{l}\text { Encouraging } \\
\text { entrepreneurial mindset }\end{array}$ & $\begin{array}{l}\text { Organizing large units into smaller product-oriented teams and } \\
\text { ensuring connections between them. Product teams gain } \\
\text { business knowledge to become capable of managing clients and } \\
\text { products to create value and quality. }\end{array}$ \\
\hline
\end{tabular}




\section{Agile Product Development Practices for Coping with a Learning Paradox in R\&D Offshore Units Janne Kuivalainen, Iivari Kunttu, Marko Kohtamäki}

\begin{abstract}
'fail quickly'. It means that I'm trying to convince people they shouldn't be afraid to try something, just to check if it's going to work or not." - Case Study A
\end{abstract}

\section{Innovative culture and structures}

In the spirit of agile development, local $R \& D$ management may also decide to make organizational changes that enable more efficient and entrepreneurial mindsets and working models. In practice, this may mean that larger units get organized into smaller product-oriented teams that have strong connections and interactions between each other:

\section{"It means the team can get knowledge, experience the capability of dealing with such products, with such clients. Really going through all details from software level to customer. Even what the customer looks like when they sleep, when they get up, why, etc., so that's the first thing. How to make sure that everything, how to build up this idea or bring this idea to the next level." - Case Study A}

As a part of the agile innovation mindset, the $R \& D$ organizations also measure how many innovative ideas from hackathons and other idea-generation workshops are delivered within the products:

\section{"[W] run innovation tournaments, [and]} innovational idea-generation, hackathons. [At] these kinds of events we measure how many ideas out of those events have been implemented within our product. It means that we can show that we took some effort to generate ideas and we already took some effort to make sure that those ideas are running things on customer sites. We measure this and we report this on a monthly basis." - Case Study A

\section{Conclusion}

This study set out to understand how local R\&D management in $R \& D$ offshore units develop capabilities for learning and innovation while simultaneously maintaining project performance. In the previous literature, this tension has been regarded as a learning paradox ( Smith \& Lewis, 2011; Jay, 2013). Following the results obtained in Kunttu and Kohtamäki (2018), and in Kunttu et al. (2019), the analysis of our work on three cases demonstrates the paradoxical tension between performance targets and demands related to innovativeness in daily $R \& D$ operations. At a general level, tension exists in knowledge-intensive $R \& D$ work where performance targets related to time schedules and project cost represent "tough targets" that must be met by R\&D organizations. In addition to these formal requirements, the local offshore unit must be able to provide added value for the parent unit by demonstrating innovativeness and capabilities for learning. In this manner, the offshore unit must be initiative-taking and innovative (Ambos et al., 2010), despite the fact that it has only minimal opportunities to affect decisions regarding their projects and resources.

The main contribution of this paper has been to present several managerial practices that managers of local $R \& D$ offshore units may use to balance between contradictory demands and project performance. The identified practices were divided into three main categories: strategy, learning, and culture. In local-level strategies, the key coping practices include initiative-taking and maintaining direct relationships with customers. In this manner, offshore units may use direct customer views and initiatives as direct inputs for their local-level innovation development. The offshore unit managers seem to use initiative-taking in arranging "flexible time" for $R \& D$ teams to develop their own innovation projects. This flexible time can be arranged by, for example, organizing R\&D work in a more agile manner, applying automated processes in administration and testing, or including some extra time in project work. Despite the fact that these kinds of arrangements are typically made without explicit approval from the parent unit, they provide the offshore unit with the only way to develop internal innovation, which in turn increases customer value and provides the unit with a competitive advantage compared to other offshore units.

Concerning the learning practices, the interviews revealed a number of local-level practices that facilitate learning and competency development. In parallel with formal learning opportunities such as training, the interviews highlighted informal learning opportunities such as hackathons, programming events, and various kinds of conferences and meetings, in which the $R \& D$ staff may gain insights into new technologies and methods. In the third category of innovative culture and structures, our research revealed that local offshore unit managers may encourage an innovation mindset in their units by arranging guided hackathons and other activities around selected innovation themes. In this context, an entrepreneurial mindset in companies has been facilitated to go along with organizational change, and by introducing performance metrics for innovation- 


\section{Agile Product Development Practices for Coping with a Learning Paradox in R\&D Offshore Units Janne Kuivalainen, Iivari Kunttu, Marko Kohtamäki}

oriented activities.

As a managerial contribution, the paper presents a number of practices that will potentially help local management in globally dispersed subsidiaries and offshore units to cope with tensions between project performance and fostering local learning and innovation. These practices relate to creating local strategies for initiative-taking in innovation development, learning, and competency development, as well as facilitating innovation management in $R \& D$ teams.

\section{References}

Ambos, T. C., Andersson, U., \& Birkinshaw, J. 2010. What are the consequences of initiative-taking in multinational subsidiaries? Journal of International Business Studies, 41(7): 1099-1118.

Andersson, U., Forsgren, M., \& Holm, U. 2002. The strategic impact of external networks: Subsidiary performance and competence development in the multinational corporation. Strategic Management Journal, 23(11): 979-996.

Birkinshaw, J., \& Hood, N. 1998. Multinational subsidiary evolution: Capability and charter change in foreignowned subsidiary companies. Academy of Management Review, 23(4): 773-795.

Bäck, I., \& Kohtamäki, M. 2016. Joint Learning in Innovative $\mathrm{R} \& \mathrm{D}$ Collaboration. Industry and Innovation, 23(1): 62-86.

Einola, S., Kohtamäki, M., Parida, V., \& Wincent, J. 2017. Retrospective relational sensemaking in $R \& D$ offshoring. Industrial Marketing Management, 63: 205-216.

Eisenhardt, K. M., \& Martin, J. A. 2000. Dynamic Capabilities : What Are They ? 1121: 1105-1121.

Figueiredo, P. N. 2011. The Role of Dual Embeddedness in the Innovative Performance of MNE Subsidiaries: Evidence from Brazil. Journal of Management Studies, 48(2): 417-440.

Jay, J. 2013. Navigating paradox as a mechanism of change and innovation in hybrid organizations. Academy of Management Journal, 56(1): 137-159.

Kohtamäki, M., Einola, S., \& Rabetino, R. 2020. Exploring servitization through the paradox lens: Coping practices in servitization. International Journal of Production Economics, (In press). https://doi.org/10.1016/j.ijpe.2020.107619.

Kunttu, I., \& Kohtamäki, M. 2018. Competing demands between innovativeness and performance targets in $\mathrm{R}$ \& D subsidiaries -the learning paradox in technology organizations. ISPIM Innovation Conference, (17-20
June, Stockholm, Sweden).

Kunttu, I., Kuivalainen, J., \& Kohtamäki, M. 2019. Balancing between learning and performance in R \& D subsidiaries of global technology companies multiple case study. ISPIM Innovation Conference, (Florence, Italy, 16-19 June).

Lewin, A. Y., Massini, S., \& Peeters, C. 2009. Why are companies offshoring innovation the emerging global race for talent. Journal of International Business Studies, 40(6): 901-925.

Marsh, S., \& Stock, G. 2003. Building Dynamic Capabilities in New Product Development through Intertemporal Integration. Journal of Product Innovation Management, 20(2): 136-148.

McEvily, B., \& Zaheer, A. 1999. Bridging ties: A source of firm heterogeneity in competitive capabilities. Strategic Management Journal, 20(12): 1133-1156.

Parida, V., Wincent, J., \& Kohtamäki, M. 2013. Offshoring and Improvisational Learning: Empirical Insights into Developing Global R\&D Capabilities. Industry and Innovation, 20(6): 544-562.

Reilly, M., Scott, P., \& Mangematin, V. 2012. Alignment or independence? Multinational subsidiaries and parent relations. Journal of Business Strategy, 33(2): 411.

Reilly, M., \& Sharkey Scott, P. 2014. Subsidiary driven innovation within shifting MNC structures: Identifying new challenges and research directions. Technovation, 34(3): 190-202.

Smith, W. K., \& Lewis, M. W. 2011. Toward a theory of paradox: A dynamic equilibrium model of organizing. Academy of Management Review, 36(2): 381-403.

Teece, D., Pisano, G., \& Shuen, A. 1997. Dynamic capabilities and strategic management. Strategic Management Journal, 18(7): 509-533.

Yamin, M., \& Andersson, U. 2011. Subsidiary importance in the MNC: What role does internal embeddedness play? International Business Review, 20(2): 151-162. 


\section{Agile Product Development Practices for Coping with a Learning Paradox in R\&D Offshore Units Janne Kuivalainen, Iivari Kunttu, Marko Kohtamäki}

\begin{abstract}
About the Authors
Janne Kuivalainen Janne Kuivalainen is head of Product Management and Development with the Drives business segment ( $€ 1,420 \mathrm{~m}$ sales in 2018) in Danfoss Corporation. Prior to joining Danfoss in early 2019, he was Head of Technology of the Global Marine and Ports Business Unit at ABB. He has also held various management positions with Danfoss, Vacon Plc, and ABB in the areas of Research and Development, Product Management, and System Integration Project Business. $\mathrm{He}$ has also contributed to IEC standardization in industrialprocess measurement, control and automation via a national working group in Finland. He holds a MSc (Eng) in Automation Engineering from Tampere University of Technology, Finland. His interests cover research activities in Strategic Business Management at the University of Vaasa.

Dr Iivari Kunttu holds a PhD in Information Technology from the Tampere University of Technology (TUT, 2005), and a PhD in Economics (Management) from the University of Vaasa, Finland (2017). Currently he acts as Principal Research Scientist in Häme University of Applied Sciences. From 2012 to 2017, he held an Assistant Professor position in the Department of Management at the University of Vaasa. He has also held several R\&D Manager and R\&D Process Development specialist positions in the Nokia Corporation, and Project Manager positions in TUT. His current research interests include R\&D and innovation management, data analysis, business development, as well as digital services. His works have been published in such international journals as Pattern Recognition Letters, Machine Vision Applications, Optical Engineering, Journal of Telemedicine and Telecare, Annals of Long-term Care, Technovation, Industry and Innovation, and Technology Innovation Management Review.
\end{abstract}

Dr Marko Kohtamäki is a Professor of Strategy at the University of Vaasa, and a Visiting Professor at the USN Business School, and Luleå University of Technology. Kohtamäki takes special interest in strategic practices, digital servitization, $R \& D$ and innovation, business models, and strategic alliances in technology companies. Kohtamäki has published in distinguished international journals such as Strategic Management Journal, International Journal of Operations and Production Management, Industrial Marketing Management, Long Range Planning, Strategic Entrepreneurship Journal, International Journal of Production Economics, Technovation, and Journal of Business Research, amongst others.

\footnotetext{
Citation: Kuivalainen, J., Kunttu, I., Kohtamäki, M.. 2020. Agile Product Development Practices for Coping with a Learning Paradox in R\&D Offshore Units. Technology Innovation Management Review, 10(3): 6977. http://doi.org/10.22215/timreview/1338 (cc) BY
}

Keywords: Learning paradox, Agile R\&D, R\&D offshoring 